\title{
FLOW SYNTHESIS AT THE TMA 550 AL FLEXIBLE MANUFACTURING CELL
}

\author{
Ovidiu MOLDOVAN \\ University of Oradea, Faculty of Management and \\ Technological Engineering \\ Oradea, Romania \\ ovidiu30@gmail.com
}

\author{
Radu Cătălin ȚARC̆ \\ University of Oradea, Faculty of Management and \\ Technological Engineering \\ Oradea, Romania \\ rtarca@uoradea.ro
}

\begin{abstract}
The paper aims to present the components and structure of the TMA 550 AL flexible manufacturing cell whit the goal of highlight the role and place of each component widen the flexible manufacturing cell and also to realise the matricial model of the flexible manufacturing cell emphasizing the relations between the various components of the flexible manufacturing cell.
\end{abstract}

\section{Keywords-flexible manufacturing, flow synthesis}

\section{PRESENTATION OF THE TMA 550 AL FLEXIBLE MANUFACTURING CELL}

The TMA AL 550 flexible manufacturing system is situated in the multidisciplinary laboratory of the Mechatronics Department of the Faculty of Management and Technological Engineering in Oradea.

The flexible manufacturing cell was built around the TMA 55 horizontal spindle work center, which was upgrades to a 5 axis machine using the FANUC 310i CNC controller.

The flexible manufacturing cell is composed of several key components.

- The horizontal spindle CNC machine

- Two ABB IRB 1600 industrial robots

- The modular system conveyor

- The storage system

- Tombstone device

\subsection{Storage system}

In the TMA 550 AL flexible manufacturing cell the storage system is a mixed centralized system. In the storage system are found both raw materials necessary for the system, tools to be used or have that have been used and also finished products.

The deposit is made entirely of standardized aluminium profiles including the connection elements. The storage capacity is 10 places for pallets. Each pallet can contain either a tool, raw material or finished product.

In terms of space occupied in the layout of the flexible manufacturing cell the storage system falls into a parallelepiped with dimensions 1900 x 1450 x $1830 \mathrm{~mm}$ [1].

The main structure of the storage system is presented in figure 1.1. In figure 1.2 is presented the removable pallet holder.

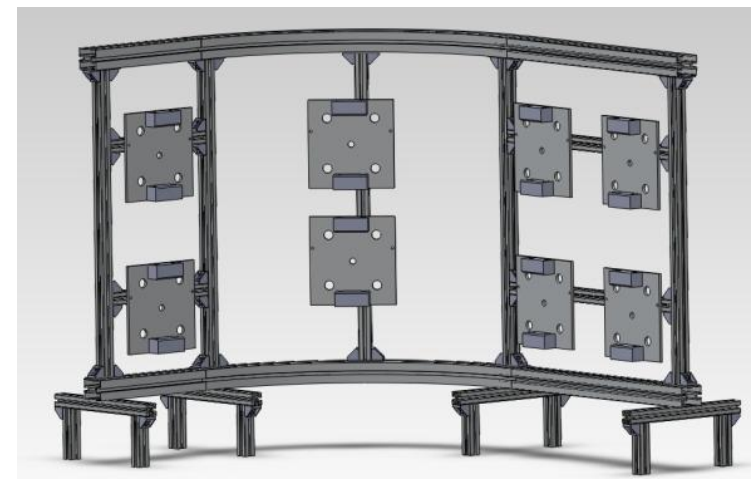

Figure 1.1 The TMA 550 AL storage system

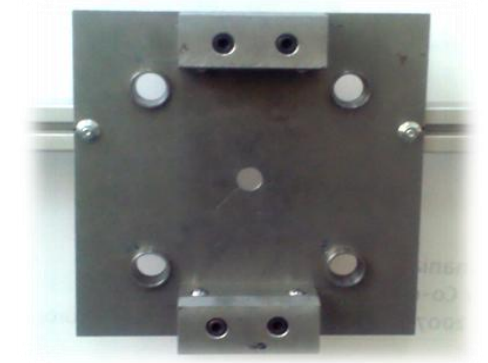

Figure 1.2. Removable pallet holder

\subsection{ABB IRB 1600 robots}

For manipulating the removable pallets trough the flexible manufacturing cell two ABB IRB 1600 industrial 
robots are used. The robots where fitted with an adequate grippers. In figure 1.3 one of the ABB IRB 1600 robot fitted with a gripper suited for manipulating the removable pallet is presented. The gripper is a pneumatic type.

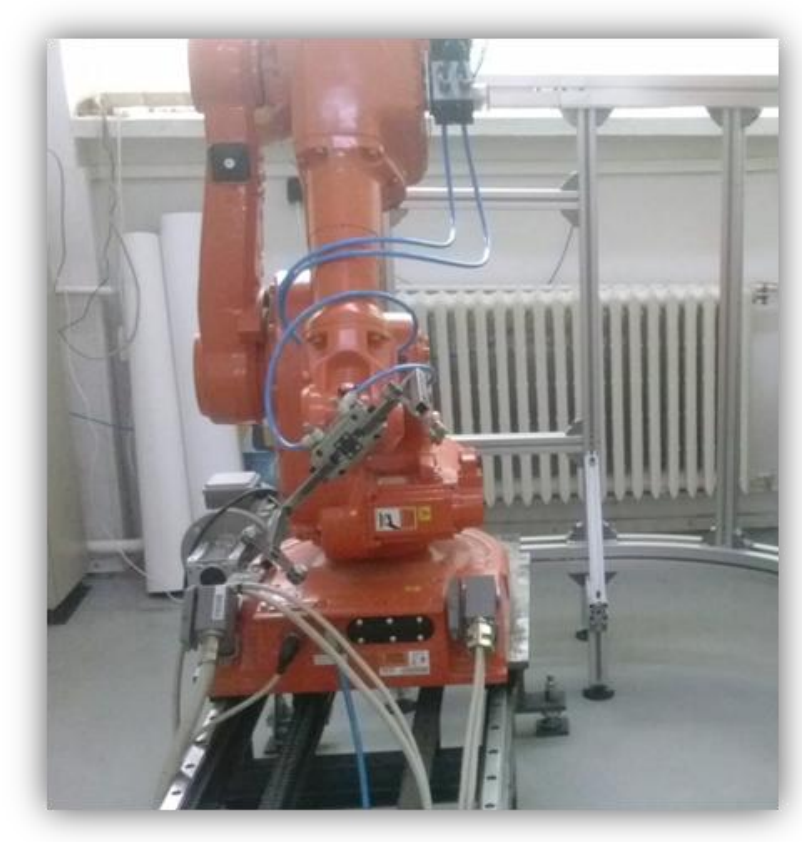

Figure 1.3 ABB IRB 1600 robot fitted with a gripper

\subsection{Conveyor}

The modular conveyor is made by the FlexLink company and allows the transfer of materials trough pallets. In figure 1.4 the $3 \mathrm{D}$ model of the conveyor is presented. In figure 1.5 the additional transfer pallets are presented. This pallets have been designed to accommodate the removable pallet and by suitable for usage with the conveyor.

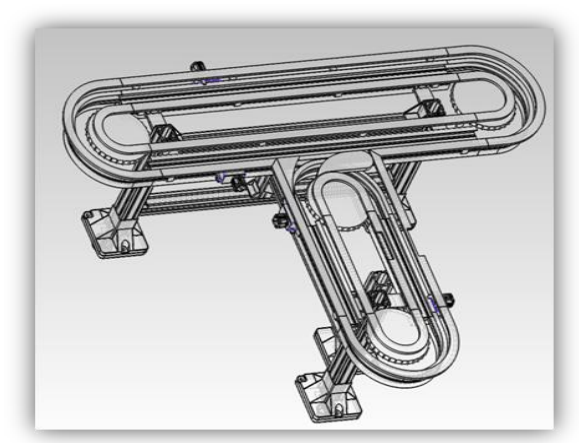

Figure 1.4. The modular conveyor-3D model.
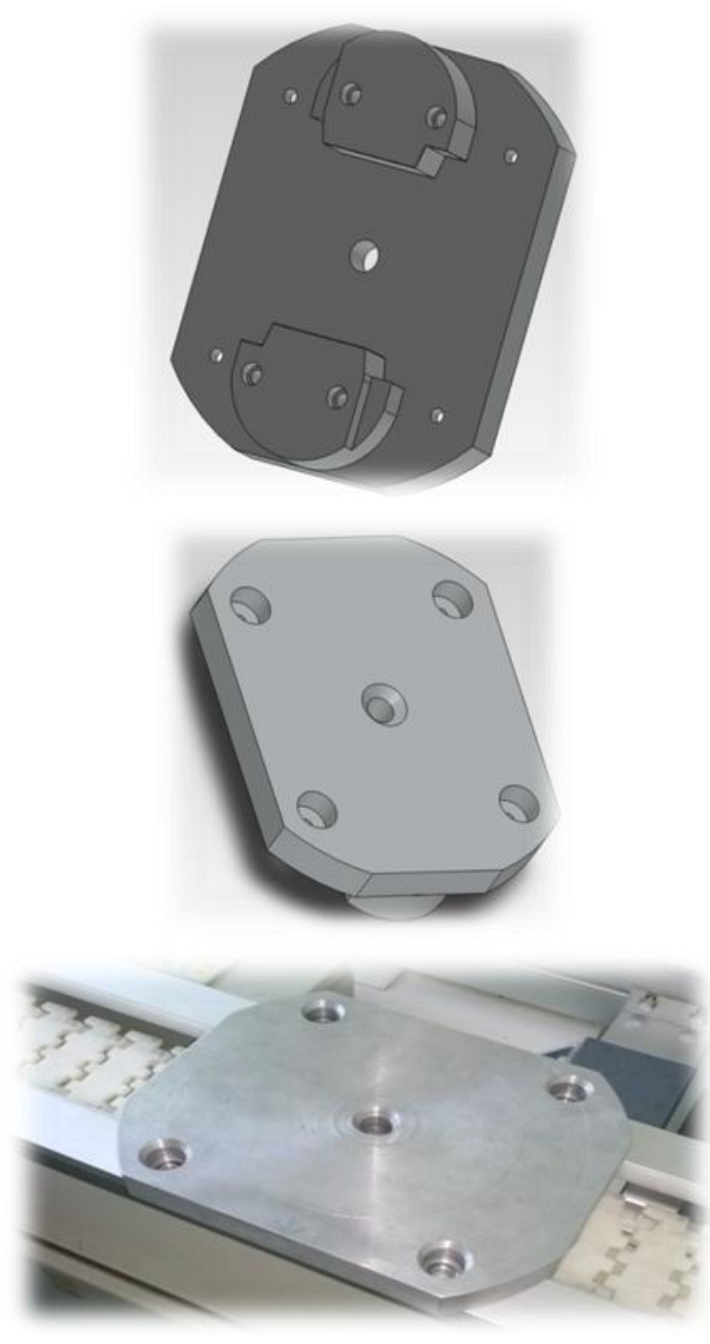

Figure 1.5 The additional transfer pallets

\subsection{Machining centre}

The AL 550 Machining Centre is having five-axis machine with a horizontal spindle and is equipped with GEFANUC CNC equipment $310 \mathrm{i}$.

The axes length of the machining centre are:

$\mathrm{X}=650 \mathrm{~mm}$

$\mathrm{Y}=650 \mathrm{~mm}$

$\mathrm{Z}=450 \mathrm{~mm}$

$\mathrm{B}=3600$ continuous $\mathrm{CNC}$ axis (360.000 pulses /rotation) $\mathrm{C}=3600$ continuous $\mathrm{CNC}$ axis (360.000 pulses /rotation) 


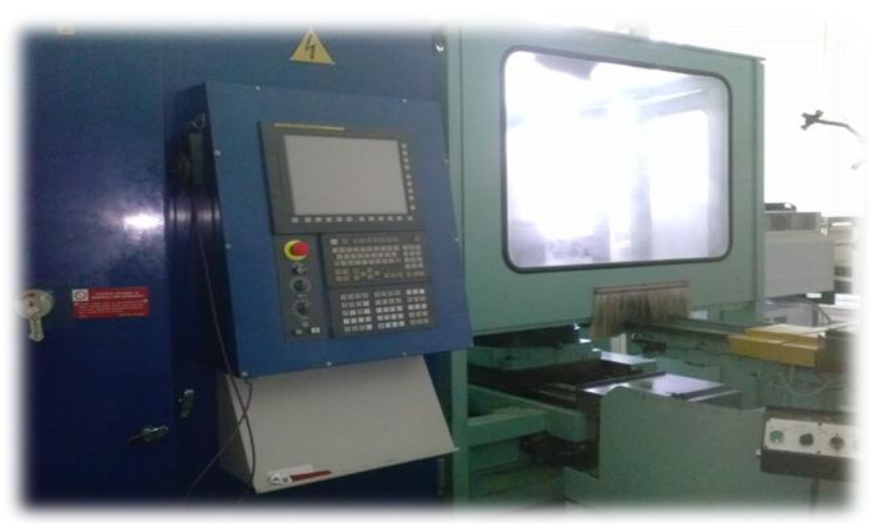

Figure 1.6. The AL 550 Machining Centre

\subsection{Layout of the TMA 550 AL flexible manufacturing cell}

The layout of the TMA 550 flexible manufacturing cell is presented in figure 1.7.
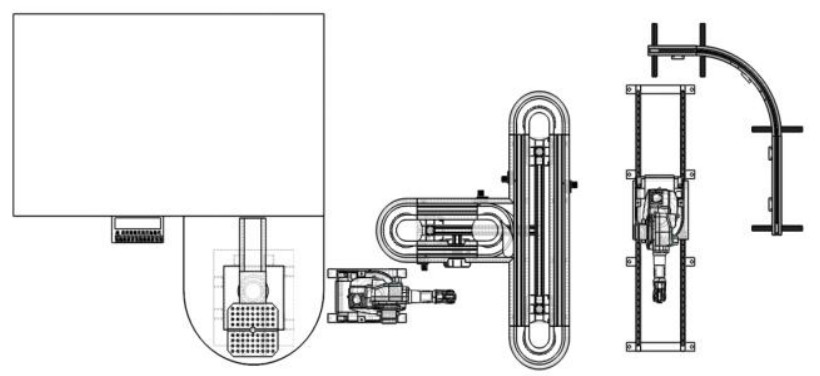

Figure 1.7. Layout of the TMA 550 flexible manufacturing cell [1]

\section{MATHEMATICAL MODEL OF MANUFACTURING CELL}

In order to determine the mathematical model of the flexible manufacturing system to highlight the connexions between the different components a flow diagram between the components of the system must be realised [2]. The diagram is presented in figure 1.8 .

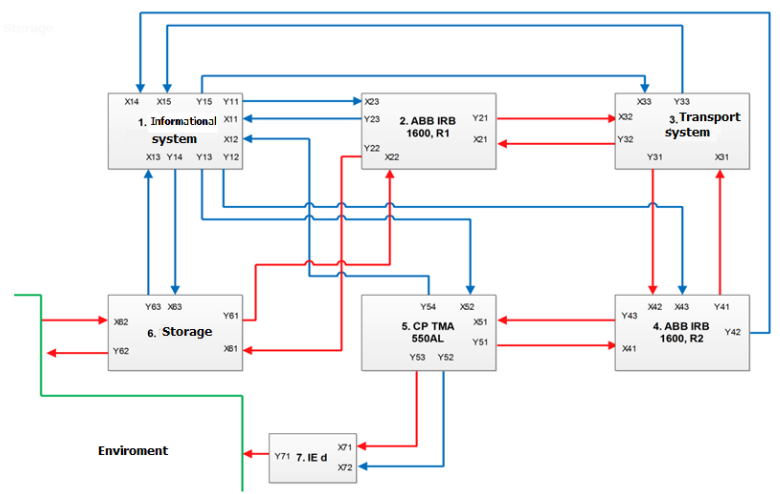

Figure 2.1. Flow diagram between the components of the system
The coupling matrices of the subsystems that make up the flexible manufacturing cell are in the following relations relationships:

$$
\begin{aligned}
\mathbf{K}_{\mathbf{1 2}}= & {\left[\begin{array}{lllll}
\mathbf{0} & \mathbf{0} & \mathbf{0} & \mathbf{0} & \mathbf{0} \\
\mathbf{0} & \mathbf{0} & \mathbf{0} & \mathbf{0} & \mathbf{0} \\
\mathbf{1} & \mathbf{0} & \mathbf{0} & \mathbf{0} & \mathbf{0}
\end{array}\right] } \\
K_{13} & =\left[\begin{array}{lllll}
0 & 0 & 0 & 0 & 0 \\
0 & 0 & 0 & 0 & 0 \\
0 & 0 & 0 & 0 & 1
\end{array}\right] \\
K_{14} & =\left[\begin{array}{lllll}
0 & 0 & 0 & 0 & 0 \\
0 & 0 & 0 & 0 & 0 \\
0 & 1 & 0 & 0 & 0
\end{array}\right] \\
K_{15} & =\left[\begin{array}{lllll}
0 & 0 & 0 & 0 & 0 \\
0 & 0 & 1 & 0 & 0
\end{array}\right] \\
K_{16} & =\left[\begin{array}{lllll}
0 & 0 & 0 & 0 & 0 \\
0 & 0 & 0 & 0 & 0 \\
0 & 0 & 0 & 1 & 0
\end{array}\right]
\end{aligned}
$$

Matrix $\mathrm{K}_{17}$ is null.

$$
\begin{aligned}
K_{21} & =\left[\begin{array}{lll}
0 & 0 & 1 \\
0 & 0 & 0 \\
0 & 0 & 0 \\
0 & 0 & 0 \\
0 & 0 & 0
\end{array}\right] \\
K_{23} & =\left[\begin{array}{lll}
0 & 0 & 0 \\
1 & 0 & 0 \\
0 & 0 & 0
\end{array}\right] \\
K_{26} & =\left[\begin{array}{lll}
0 & 1 & 0 \\
0 & 0 & 0 \\
0 & 0 & 0
\end{array}\right]
\end{aligned}
$$

Matrices $\mathrm{K}_{24}, \mathrm{~K}_{25}, \mathrm{~K}_{27}$ are null.

$$
\begin{aligned}
K_{31} & =\left[\begin{array}{lll}
0 & 0 & 0 \\
0 & 0 & 0 \\
0 & 0 & 0 \\
0 & 0 & 0 \\
0 & 0 & 1
\end{array}\right] \\
K_{32} & =\left[\begin{array}{lll}
0 & 1 & 0 \\
0 & 0 & 0 \\
0 & 0 & 0
\end{array}\right] \\
K_{34} & =\left[\begin{array}{lll}
0 & 0 & 0 \\
1 & 0 & 0 \\
0 & 0 & 0
\end{array}\right]
\end{aligned}
$$

Matrices $\mathrm{K}_{35}, \mathrm{~K}_{36}, \mathrm{~K}_{37}$ are null

$$
\begin{aligned}
K_{41} & =\left[\begin{array}{lll}
0 & 0 & 0 \\
0 & 0 & 0 \\
0 & 0 & 0 \\
0 & 1 & 0 \\
0 & 0 & 0
\end{array}\right] \\
K_{43} & =\left[\begin{array}{lll}
1 & 0 & 0 \\
0 & 0 & 0 \\
0 & 0 & 0
\end{array}\right] \\
K_{45} & =\left[\begin{array}{lll}
0 & 0 & 1 \\
0 & 0 & 0
\end{array}\right]
\end{aligned}
$$

Matrices $\mathrm{K}_{42}, \mathrm{~K}_{46}, \mathrm{~K}_{47}$ are null. 
$\begin{aligned} K_{51} & =\left[\begin{array}{llll}0 & 0 & 0 & 0 \\ 0 & 0 & 0 & 1 \\ 0 & 0 & 0 & 0 \\ 0 & 0 & 0 & 0 \\ 0 & 0 & 0 & 0\end{array}\right] \\ K_{54} & =\left[\begin{array}{llll}1 & 0 & 0 & 0 \\ 0 & 0 & 0 & 0 \\ 0 & 0 & 0 & 0\end{array}\right] \\ K_{57} & =\left[\begin{array}{llll}0 & 0 & 1 & 0 \\ 0 & 1 & 0 & 0\end{array}\right]\end{aligned}$

Matrices $\mathrm{K}_{52}, \mathrm{~K}_{53}, \mathrm{~K}_{56}$ are null

$$
\begin{aligned}
K_{61} & =\left[\begin{array}{lll}
0 & 0 & 0 \\
0 & 0 & 0 \\
0 & 0 & 1 \\
0 & 0 & 0 \\
0 & 0 & 0
\end{array}\right] \\
K_{62} & =\left[\begin{array}{lll}
0 & 0 & 0 \\
1 & 0 & 0 \\
0 & 0 & 0
\end{array}\right]
\end{aligned}
$$

Matrices $\mathrm{K}_{63}, \mathrm{~K}_{64}, \mathrm{~K}_{65}, \mathrm{~K}_{67}$ are null. Matrices $\mathrm{K}_{71}, \mathrm{~K}_{72}, \mathrm{~K}_{73}$, $\mathrm{K}_{74}, \mathrm{~K}_{75}, \mathrm{~K}_{76}$ are null

The structure matrix is presented in the relation

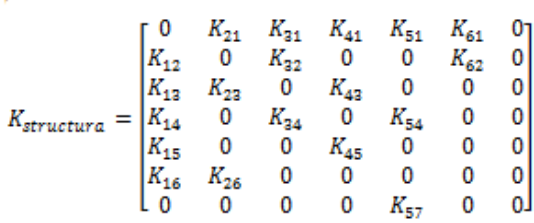

\section{Acknowledgment}

“THIS WORK WAS PARTIALLY SUPPORTED BY THE STRATEGIC GRANT POSDRU 107/1.5/S/77265 (2010) OF THE MINISTRY OF LABOR, FAMILY AND SOCIAL PROTECTION, ROMANIA, COFINANCED BY THE EUROPEAN SOCIAL FUND - INVESTING IN PEOPLE.'

\section{References}

[1] Moldovan Ovidiu - Contributii privind sistemul de gestiune a sculelor la celule flexibile de fabricație a pieselor prismatice, Oradea 2013

[2] Francisc Kovacs și Radu Cătalin Țarcă, Sisteme de fabricație flexibilă.: Editura Universitatii din Oradea, 1999, ISBN 973-941643-8.

[3] Husi Géza; Darai Gyula: Improving Education Quality By Using High Technology Devices 14th Building Services, Mechanical and Building Industry Days. 462 p.Debrecen, Magyarország, 2008.10.30-2008.10.31. 